\begin{tabular}{c} 
Volume and Issues Obtainable at Center for Sustainability Research and Consultancy \\
Journal of Business and Social Review in Emerging Economies \\
ISSN: $2519-089 X(E): 2519-0326$ \\
Volume 6: Issue 4 December 2020 \\
JSRᄃ \\
Journal homepage: $\underline{\text { www.publishing.globalcsrc.org/jbsee }}$ \\
\hline
\end{tabular}

\title{
Nigeria's First Republic and Post 1966 Federalism: A Comparative Study
}

\section{${ }^{1}$ Isah Shehu Mohammed, ${ }^{2}$ Muhammad Fuad bn Othman, ${ }^{3}$ Nazariah binti Osman}

Chief Lecturer, Head of General Studies Department, Federal Polytechnic, Bauchi - Nigeria zababa72@yahoo.com

${ }^{2}$ Professor, Assistant Vice Chancellor and Dean, School of International Studies, Universiti Utara, Malaysia, mfuad@uum.edu.my

${ }^{3}$ Senior Lecturer, Deputy Dean, School of International Studies, Universiti Utara, Malaysia nazariah@uum.edu.my

\begin{tabular}{l}
\hline ARTICLE DETAILS \\
\hline History: \\
Revised format: November \\
2020 \\
Available Online: December \\
2020
\end{tabular}

Keywords:

Autonomy, Constitution, Federalism, First Republic, Nigeria, Power

\section{JEL Classification:}

M10, M38

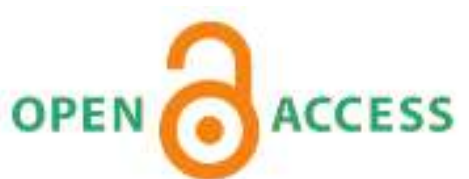

\section{ABSTRACT}

Objective: The objective is to make a comparative study of the Nigeria's First Republic (1954-1966) and the post 1966 federalism. The two periods saw Nigeria practicing federalism with different power sharing and governmental components arrangements. The study is significant at this time of search for a viable federalism, incessant agitations for restructuring the Nigerian state, and increasing threats to her unity and cohesion over the federal arrangement. Methodology: The study used non-numerical, secondary and historically documented sources to collect data and also used the historical method and practical events in Nigeria's journey of federalism to analyse the data. Result: In the First Republic, it was a fiscal federalism with greater regional autonomy and limited constitutional powers to the Central Government, while the post 1966 federalism had more and strategic powers constitutionally allocated to the Central Government. First Republic federalism was more disciplined in financial and residual matters and power with greater autonomy and competition between regions which greatly fostered development and accountability among them, with less constitutional frictions between the Central and Regions. Implication: The study fills an existing gap in the study of Nigeria's federalism viz-a-viz more calls for restructuring and or true federalism, number of units and devolution of constitutional powers, corruption, slow and discouraged development, which result in over reliance on statutory allocations from the Centre, and intensifies struggle for resource control, although it on the other hand controversially guarantees the unity of the Nigerian state.

(C) 2020 Center for Sustainability Research and Consultancy Pakistan under a Creative Commons Attribution-NonCommercial-

ShareAlike 4.0

Corresponding author's email address: zababa72@yahoo.com

Recommended citation: Mohammed, I. S., bn Othman, \& Binti Osman, N. (2020). Nigeria's First Republic and Post 1966 Federalism: A Comparative Study. Journal of Business and Social Review in 
Emerging Economies, 6(4), 1469-1478

\section{Introduction}

States and nations have historically been characterized by the search for, evolution, adoption or adaptation of varying and systems of government relative to their socio-economic, political, geo-physical and historical peculiarities. For Nigeria as well, the search has also been determined and influenced by these factors, but gruesomely affected by colonialism (1861-1960). Colonialism not only affected the search, but made a significant impact on the state, political system and the society in such a way that departure from it has become near impossible, especially with regards to the burdens of colonial history (Unegbu 2003:41-48), experience and engravings which Nigeria has been battling with since her amalgamation British colonialism and in the post independence era. One of such burdens is the federal system of government which became imperative to both the colonialist and Nigerian nationalists on the eve of and after the independence in 1960.

From 1954 to date through the battle and carrying the burdens of the colonial history, Nigeria has since October 1954 been under the federal system, (except for General Ironsi's regime, January-July, 1966), but still battling with choice of the most feasible federal arrangement for its heterogeneous make-up. With those - colonialism, independence and heterogeneities of the Nigerian nation have altogether been shaping the post independence era and destiny (Suleiman \& Maiangwa, 2017:262). The past 64 years have been experimental in the practice of federalism, yet not a single mode of its adoption or adaption has been commonly reached by the stakeholders.

This study explores and compares the two major periods of practicing federalism in Nigeria - the 19541966 (late Colonial period, First Republic, early independence and Republican era), and the post 1966 federalism largely determined and influenced by the Nigerian military in addition to other factors.

\subsection{Statement of the Problem}

Nigeria federalism is confronted with varying challenges which are more often not based on the conception and or traditions of the conventional federalists, and which therefore, require contemporary, situational and unique approaches and actions other than those conventional principles (Othman, Osman \& Mohammed, 2019; Mohammed \& Aisha, 2020; Adedeji \& Ezeabasili, 2018:167); Adoption or adaption and operation of feasible federalism, including states creation and revenue allocation have been the main challenges confronting the growth and development of Nigeria (Ahmed, Falaye, Oloni, \& Okeke, 2017:1; Shagari, 2001; $273 \&$ 276); The failure to address, arrive at compromised and popular federal structure has led to 'tragic policy failure' in Nigeria, while openness, responsibility and responsiveness among the levels of the Nigerian federalism have remained only elusive and poorest in performance ranking (Friedman, 2018:165; Anderson, 2012).

With the much bound colonial heritages, Nigerians have failed to forge ahead and resolve disunity, ethnoregional and religious antagonism and conflicts (Saidu, Rasheed, Zakuan \& Yusoff, 2019; George, Yusuff \& Cornelius, 2017; Suleiman \& Maiangwa, 2017:273; Fessha, (2017; Mohammed \& Aisha, 2020); British colonial legacies have resulted in transformed religious, ethno-regional and political identities for the Nigerian state, and the greatest challenge to federalism and nation-building; Although ethno-federalism was initially regarded as the solution to Nigeria's heterogeneous composition, it is still responsible for the ethno-religious sentiments in the later Nigeria, particularly among the common men (Suleiman \& Maiangwa, 2017:269; Ejobowah, 2010); The minority issue is also key to discussions on Nigerian federalism, but has lingered on and hit the federal structure and operation since the inception of the Nigerian state system (Usuanlele \& Ibhawoh, 2017:2). The conglomeration of these problems have resulted in calls for restructuring (centred on fiscal federalism) the country, as well as the attendant manipulation and hijack of the calls by the ethno-religious, regional elites and politicians, among others.

\subsection{Background of the Study}


The controversial, but un-ignorable statement by Verjee (2017: ix) that 'anyone who claims to understand Nigeria is either deluded, or a liar' has a significant impact. Nigeria, the leading West African and African state is also the largest single black federal democracy in the world. It is strategic in both the regional, continental and world affairs, especially for its political significance to the regional security, the Commonwealth, global oil market and economy, and its large population of over 193m people (Idris, 2018; Mohammed \& Aisha, 2017; NBS, 2016). Nigeria is the result of the amalgamation of numerous heterogeneous, geo-political, ethno-religious and political entities by the British colonial masters in 1914. Hence the earlier admission that the name Nigeria 'is only an English expression of which has been made to comprehend a number of natives covering about 500,000 square miles of territory of the world' (Lugard, 1906:7). All these however, began when Africans (who then had no say) and their lands were apportioned among the then world imperial powers at the Berlin Conference, 1884-1885 (Usuanlele \& Ibhawoh, 2017:1). The composition of the amalgamated Nigeria transcends beyond ethnicity and religion, but also geography, history, culture, civilization and worldview, among others.

From the first day of its amalgamation, Nigeria has deliberately and otherwise, been engaged in the search for the popular and feasible means of being together and nationhood amidst the heterogeneities and colonial bondage. One of such has been the adoption of federalism in the mid 1950's, which is a means of resolving conflicts among citizens and levels of government, especially in heterogeneous states (Amusan, Saka \& Omede, 2017:3; Deng, Deng, Deng \& Jiménez, 2008). It has therefore not been an easy journey for Nigeria through the nationhood through the over 106 years of amalgamation. However, despite the challenges, as maintained, 'the construction of Nigerian nation, its resilience in the face of historical and geographical adversity, and its progress following the unexpected traumas of the post-independence era, are enduring testaments to its people and proof of its promise' (Levan \& Ukata, 2018:1). Furthermore, the British policy of indirect rule required homogeneity and establishment of tribal hierarchies and those resulted in the post-colonial bond and reconfiguration of ethno-religious and geo-political problems in the former colonies. This necessitates the continuous battle with the challenges of unity and cohesion among the former colonies, especially Nigeria (Usuanlele \& Ibhawoh, 2017:2).

Many instances influenced the choice of federalism for Nigeria, including the colonialists themselves and the 1953/54 London/Lagos Constitutional Conference which agreed to among others to institute fiscal arrangements in a new constitution and a federal system of government for Nigeria (Shehu \& Buba, 2016:89-90). Similarly, Sir Tafawa Balewa (Tafawa Balewa, 1962:2) had in that respect maintained that:

I am pleased to see that we have all agreed that the federal system is, under the present conditions, the only basis on which the Nigeria can remain united. We must recognize our diversity and the peculiar conditions under which the different communalities live in this country. To us in Nigeria therefore unity in diversity is a source of great strength, and we must do all in our power to see that this federal system of government is maintained and strengthened.

Although from the late 1940s and early 1950s, political organisations and parties were formed mainly based on ethno-regional lines which greatly influenced and shaped the political atmosphere of the Nigerian state, the 'tenuous consensus' was reached by both colonial masters and the then Nigerian politicians/regional leaders that federalism would be the best for Nigeria, especially with respect to its heterogeneous character (Usuanlele \& Ibhawoh, 2017:5).

Similarly, the 1994/95 Abacha Constitutional Conference Committee in its final Report observed and recommended that Nigeria should adopt a federal system with central government having substantial distribution of powers and autonomy with coordinate functions/powers in order to maintain unity and autonomy among the Nigerian communities, and also beneficial to the heterogeneity of Nigeria and sustain its unity in diversity; ensure participation in governance; minimize fears of domination; and foster development. The Conference also recommended operation of federalism with clear demarcation of the powers, equitable distribution of economic and political powers between the centre and the other units, 
strong and independent Judiciary, and economically viable components units that would not be so much dependent on the Centre and central resources (Dinneya, 2006; THISDAY, 1998. November 17, pp. IXLIV).

On the other hand, the history and practice of federalism in Nigeria has been both dominated and hit by the Nigerian military. Despite the political scientists submission, especially from the Western world, that military rule is incompatible to federalism because of the absence of popular participation in governance, non-democratic character and unbinding and less accountability to the electorate. However, all the Nigerian military regimes, but one (Ironsi) have adopted federalism and sought to improve its practice at varying levels and degrees (Elaigwu, 2017:11-12). This means the Nigerian military have despite their authoritarian character, been able to work with federalism at varying degrees.

\subsection{Conceptualisation and Review}

Despite the existence and usage of theories on federalism (Mohammed \& Aisha, 2020), it has no any universally accepted and full pledged theory and no state has been able to practically adopt all the principles of federalism in its traditions (Mohammed \& Aisha, 2020; Elaigwu, 2017:7; Burgress, 2006:1). Thus for Ayoade in Elaigwu \& Akindele (1996:40), 'Federalism is dialectical. It is necessitated by the emotions of love and hate. The success of federal experiment is a function of equilibrium between both feelings'. However, Wheare (1963) identifies the basis of federalism as the existence of a written constitution, constitutional division of powers, and autonomy of the respective units in exercise of powers and functions. In reality, Nigerian federalism and its inherent characters have raised and encouraged springing and proliferation of ethno-religious militia groups that threaten the sustenance and prosperity of both the federal arrangement and the state system (Babawale, 2001). Similarly, the desire and clamour for fiscal federalism has in addition to corruption and elite manipulation, been also a generator and determinant of resource control conflict, heated debates, and eruption of violent struggles, especially in the oil producing areas of Nigeria (Aka, 2017; Charles, 2013; Salami, 2011; Arowola, 2011).

For Nigeria, fear of domination has since the inception of the federalism and later the creation of 12 states in 1967, generated fear, mistrust and suspicion among the majority groups on one hand, and on the other, the Niger-Delta region composed of numerous and ethnic groups in a complex environmental set-up stricken by fear of domination of one another and resource conflict (Othman, Osman \& Mohammed, 2019; Mohammed, Othman \& Osman, 2019). So also to the Middle-Belt/Central Nigerian minorities on the Northern part and those have been a thorn to the Nigerian federalism (Levan, 2018). For Elaigwu \& Erim (1996:1), there are 5 contrasting perspectives on Nigerian federalism as: the federalism was imposed on Nigeria by the British, it was British policy of divide and rule, that federalism or confederalism is invariable to Nigeria's heterogeneous composition, federalism is a compromise among Nigerians, and a mixture of centrifugal and centripetal factors. The military has similarly been dominant in the Nigerian federalism ever since the January 1966 coup and hand hence, played the most significant role in shaping the federalism through Decrees, Edicts, States and Local Government creations, and revenue allocation among others. Thus resulting to and entrenching what Elaigwu (2017) terms as Military Federalism.

\subsection{Perils of Nigerian Federalism}

The peculiar perils of Nigerian federalism have from pre-independence to date characterized and complicated it with several instances, occurrences and recurrences - oil rent dependent economy, difficult colonial burden of history and heritages, ethno-regional politics, recurrence of violence, rise of ethnic militias and separatist tendencies, and elites' competition and manipulation of state power and resources (Levan, 2013; Mohammed, et al, 2019). Added to that, Nigeria is a resource rent dependent federation with over dependence on oil which is explored from the Niger-Delta - an area already heated with minorities' suspicion, fear and resentment of the majority apart from resource conflict (Amusan, et. al., 2017:3). Although substantial revenue has been realized over the years since the discovery and exploration of oil in Nigeria, not much in commensurate with the generated revenue has been achieved in terms infrastructural, and socio-economic development. Instead, only few and privileged elites have access to 
the oil resources and what accrues from it thereby resulting in violence, pervasive corruption and negligence and near crash of the non-oil sectors, and mortgaging the oil resources and revenue at the expense of stability, development and prosperity of Nigeria (Mohammed, Saidu \& Aisha, 2018; Amusan, et. al, 2017:18).

The search for a popular federalism in Nigeria is greatly influenced by the desire of the resource-rich areas, communities and regions that largely depend resource rent in order to control such resources endowed in their areas, especially oil (Othman, et al., 2019; Amusan, et. al., 2017:4). Thus federalism and oil resource constitute a volatile mix, as there often arise tensions (vertical and horizontal) over the distribution and management of rents accruable to the state from crude oil (Anderson, 2012). This is in company of the fears of the minority groups under the Nigerian state and federalism as the Willink Commission (1958) outlined and included the domination of government by the ethno-regional majorities; social fears and grievances; economic discrimination; discrimination in public recruitments, posts, and services; changes in regional legal systems; maintaining public order and the individual citizens' freedom; religious intolerance; and native authorities and traditional rulers (Usuanlele \& Ibhawoh, 2017:2; Elaigwu, 2017:46). These are in addition to two other critical perils to Nigerian federalism - imbalanced political structure between the Northern and Southern regions which results in mutual fear, suspicion, rivalry and ethno-regional nationalism; and the fear between the major ethnic groups on one hand and the minority groups fears of the majority (Hausa/Fulani, Igbo and Yoruba) on the other (Elaigwu, 2017:46).

One of the central fears of domination lies in the North's dominance in terms of population, geographical size, endowed material resources (apart from oil), and its pre-colonial historio-religious civilisation and political background, and prominence over the Southern region during colonialism, despite being (the North) late in colonization and considered educationally backward (Mohammed, 2018; Othman, et al., 2019). Suffice to say that for over two millennia, Northern region of Nigeria has been politically, commercially, and intellectually on the outer peripheries of the Mediterranean and the Middle-East. There were routes through the Sahara which linked the Coptic speaking Egypt, Phoenician Carthage, and the Roman Empire to peoples around Lake Chad and on the Great Plains to the West and the East of the Lake. While the then shores of the Sokoto Caliphate extended to as far and wide as Dori and Liptako in Burkina with commercial, religious and diplomatic relations (Last in Levan \& Utaka, 2018:19 \& 22).

The other perils of federalism in Nigeria revolve around over dependence on oil resource as a means of revenue, dominance of the central government with lion's share from the allocation of the revenue accruing to the federation, incessant disagreements and conflicts over revenue allocation, and poor fiscal relations among the units, North-South fear of hegemony, and failure to adhere to the established constitutional provisions in the practice of the federalism (Mohammed, et. al., 2018; Ewetan, 2012:1084). As a result of the above, the various Nigerian regimes have used granting autonomy to the 3 later 4 regions of Nigeria, more States and Local Governments, re-distribution and review of revenue allocation formula, bi-cameralism, among others, in order to absorb the shocks of the federalism (Levan, 2018; Friedman, 2018:165).

\section{Comparative Structure - 1954-1966 and Post 1967 Federalism}

The operation of Nigerian federalism can be practically divided into phases of the pre and First Republic (1954-66); and post 1966 which also extends to the present (2020), and including the military eras. Although the First Republic federalism under this study also covered the last part of pre-independence (1954-60), the January 1966 coup had disrupted not only the federal system, but also the proscribed democratic First Republic itself. For the post 1966 federalism, it was largely an imposition of the military regimes of Generals Gowon, Murtala/Obasanjo, Buhari, Babangida, Abacha and Abdussalam, except for the civilian Shehu Shagari's Second Republic (1979-1983). The Shagari's Second Republic/regime itself inherited all its structures of federalism from the ousted military regime of Generals Murtala/Obasanjo who successfully built on what General Gowon's military regime had earlier established - a federalism with strong Centre and weak 12 States each with their Provinces and later 19 States and 301 Local 
Government Areas (Mohammed \& Aisha, 2020; Mohammed, et al., 2018).

\section{1954-1966 Constitution of the Federation/Federal Republic of Nigeria}

The 1954-66 federalism was the result of the various constitutional conferences, in Lagos, London, Ibadan, compromises and colonial influences driven by the desire for independence, regional political, economic, geo-ethnic security and autonomy, but the military was not part of the negotiations. Under the 1954-66 federalism/constitutional power sharing in Nigeria, there were three Lists - Exclusive, Co-current and Residual Lists for the Federal/Central Government only, the 3 (later 4) Regions and the Federal Government together, and the for the Regions only and respectively. There were altogether 44 items under the Exclusive List as: Aviation, Currency, Extradition, Accounts of the Federation, Defence, Customs and Excise, among others. There was also the Con-current List with 28 items which included: Arms and Ammunitions, Registration of Business names, among others. The Residual List for the Regions (each) comprised of any matter not included in the 44 and 28 Exclusive and or the Con-current legislative Lists. The constitutional arrangement of power-sharing was with weak Central Government with limited exclusive powers and Strong Regions with enormous Residual powers. Therefore, Nigeria was a federation with Federal/Central Government and 4 Regions among whom the constitutional powers were allocated and devolved.

The 1954-66 federalism was operated with Parliamentary Democracy with offices of Prime Minister and Ceremonial President; a non-Republican Constitution, until October, 1963; three and later four Regions West, East, and North, and later the Mid-West; Premiers and Ceremonial Governors for each Region; constitutional power-sharing which granted greater autonomy to the Regions; division of constitutional powers/legislative lists into the Exclusive (Federal or Central Government only), Con-current (Federal and Regional Governments together), Residual (Regions only). It was also federalism operated with Collective Responsibility, Fusion of Powers, Dissolution of the Parliament, no cross-carpeting for the legislators; each Region had a Premier and an Executive Council, a Ceremonial Governor and Bi-cameral Regional Legislature (Houses of Chiefs and Assembly) comprising of nominated and elected members respectively; the tenure for the Executive and Legislators was 5 years at both the Central and Regional levels (all tenures were renewable after every 5 years, but without limit).

The federal Prime Minister, Regional Premiers, and the parliamentarians could be removed from office through Vote of No Confidence and or Dissolution of the Parliament; there was no Separation of Powers between the Executive and the Parliament at the Central and Regional levels; the 1959 and 1964 Central Governments were both formed through Coalition and or Alliance between the Northern Peoples Congress (NPC) and the National Council of Nigerian Citizens NCNC in the famous 1959-1964 NPC/NCNC Coalition; and the Northern Peoples Congress NPC and Nigeria National Democratic Party (NNDP) Alliance of 1964 popularly known as the Nigeria National Alliance (NNA) respectively (Mohammed, Aisha \& Saidu, 2018:59, 66, 68). The military had no role/influence in making/enacting the Constitution/federal system between 1954 and 1966, but strictly colonial and indigenous politicians' makings. Similarly, the 1954-1966 federal arrangement gave both the Central and Regional Governments the autonomous powers to each, have Central and Regional Constitutions, Coat of Arms, Police, substantial of their respective control resources, revenue generation and expenditure (Mohammed \& Aisha, 2020).

The federal powers were exercised together by the federal Prime Minister as the Executive Head of the Government, the Governor-General (later) Ceremonial President as the Head of State and Commander in Chief of the Nigerian Armed Forces, and the Federal Parliament which comprised of bi-cameral legislature from December 1959 with 312 (later 320) Representatives and 44 Senators.

\section{The Post 1966 Federalism}

For the post 1966 federalism, it was wholly a making and an imposition by the Nigeria Military resulting from the circumstances and events of the January and July 1966 coups, the abrogation of the former 
Federal System and Constitution, imposition of a Unitary Government, the assassination of General Ironsi and the Nigerian Civil-War. Thus there were Decrees No. 24 of May 1999, No. 14 of 1988, No. 3 of 1994, etc. It was military and centralist federalism (Elaigwu, 2017), with dominance of the Nigerian Military in both the political process and activities, and governance. Instead of the former 4 Regions (North, East, West and the Mid-West), 12 States and Provinces, 19 States and 301 Local Government Areas (LGAs), 21, 30 and 36 States with 768 LGA and 6 Area Councils (AC); three tier federalism with Federal/Central, States and Local Governments as units/levels of the Nigerian federation (Section 3 [1-4], 7[1-6], First Schedule [Part I], \& II of the 1999 Constitution of the Federal Republic of Nigeria). It has been a Presidential System of Government with tenure of 4 years and renewable once (Section 130[1] of the Constitution of the Federal Republic of Nigeria, 1999); the President is the Head of State, Government and Commander in Chief of the Armed Forces of the Federal Republic of Nigeria and can be removed from office through Impeachment (Section 130[2], 135, 143 of the Constitution of the Federal Republic of Nigeria, 1999).

Although it is a general position in the post 1966 federalism that with allocation of most and strategic powers (Exclusive) to the Central Government, the States are rendered weak and then dependent on the Centre for funds allocations, strategic legislations, among others, stability of income from the statutory allocations to the states has empowered the States in such ways that they exercise substantial influence and control over national resources and revenue distribution (Levan, 2018; Section 162 (3\& 4) of the Constitution of the Federal Republic of Nigeria, 1999).

The 1999 Constitution of Nigeria comprises of 68 items under the Exclusive List for the Federal/Central Government as well as any other matters that incidental and or supplementary to those in this List on which the National Assembly has jurisdiction to make laws on; 30 items under the Con-current List and the Residual List (matters not covered in the Exclusive and Con-current Lists) for the States (Second Schedule [Section 4], Part II; Fourth Schedule [Section 7] of the Constitution of the Federal Republic of Nigeria, 1999). Similarly, in the provisions of the 1999 Constitution of Nigeria, there exists a hierarchical order of levels and relations among the Central, States and the Local Governments which then confers enormous constitutional (Exclusive) powers on the Central Government over the States and Local Governments (Adedeji, 2017). There are currently 768 LGA; and 6 Area Councils for the Federal Capital Territory, Abuja (Section 3 [1-7] \& First Schedule [I \& II] of the Constitution of Nigeria, 1999).

The post 1966 federalism has been wholly Republican (including such acclamations by the Military), bearing the name of the Federal Republic of Nigeria during both the Military and civilian democratic regimes. For the civilian democratic regimes (Presidents Shagari, Obasanjo, Yar'Adua, Goodluck, and currently Muhammadu Buhari), the federalism operates with the principles of Separation of Powers, Independence of the Judiciary, Checks and Balance and a more centralist tendency in constitutional allocation of powers, among others. Similarly, that federal system has federal powers exercised by the offices of the President (Head of State and Government/Chief Executive Officer, and Commander in Chief of the Nigerian Armed Forces), and the National Assembly. The post 1966 National Assembly comprised of 1979-1983 - 96 Senators and 450 Representatives (Shagari, 2001:249); 1989-1993 - 91 Senators and 589 Representatives; from 1999 to date, 109 Senators and 360 Members for the Federal House of Representatives (Sections 49 \& 77[1] of Constitution of the Federal Republic of Nigeria, 1999).

By comparison, the Legislative items under the Con-current Powers in the 1954-66 Federalism and Constitution, but moved to Exclusive Powers in the post 1966 federalism include: Arms and Ammunitions, Bankruptcy and Insolvency, Drugs and Poison, Finger Prints, National Parks, Prisons, among others (Second Schedule [Part II, 1999 Constitution of the Federal Republic of Nigeria]). While the pre 1966 federalism and Constitution allocated those to the Con-current Lists/powers which conferred enormous powers on the three and later four Regions in addition to the bulk of Residual Powers not covered by the Exclusive and Con-current Lists. By implication, in the 1954-66 Nigerian federalism, there were 44 and 28 items for the Exclusive and Con-current powers, and for the post 1966, especially the current 1999 
Constitution, 68 and 30 items are respectively under the Exclusive and Con-current lists, while all the others are reserved for the Residual List. Furthermore, the 68 items covered all the strategic and grey areas of Mines and Minerals, Revenue, Military, External Affairs, Security, Defence, International Relations, Arms and Ammunitions, Census, Internal Affairs (Prisons, Immigration, Customs, and Police), Labour and Trade Unions and Minimum Wages, among others.

\section{The Way Forward}

Although Nigeria has been practicing federalism for over 66 years, it is yet to arrive at any nationally agreed arrangement of the federal structure. It is imperative that Nigerians must first understand that different countries practice federal system based on their peculiar differences and as such make unique arrangements for the practice of same. Issues of transparency and good governance are key to achieving success in the practice of whatever federal arrangement arrived at. It would certainly not be much easy to return to the First Republic federal structure, but its certain elements are still relevant and can be used to arrive at a popular structure for the present. While differences have to be accommodated in the federal set up, insignificant differences should be de-emphasised so as to give way forward. The tendency of the Central Government taking up much of the strategic powers should also re-directed so that the component parts may also have significant power exercise in the system. States should also enjoy further autonomy in control of their resources so as to reduce the extents of corruption and over dependence on the allocation from the Centre. The Central Government should largely concentrate on powers that have to do with ensuring and consolidating the unity of Nigerian state such as Census, Citizenship, and Passport among others, thereby leaving other powers to the components for better management and services delivery.

\section{Summary and Conclusion}

There is no doubt on the position of politicians, scholars and other stakeholders that the only system that could hold Nigeria as one and united entity at the moment is federalism. The choice of the federalism and its character, however, largely depend on a common stand reached by Nigerians. Two major federal arrangements were each tested and each has its both sides of strength and weaknesses. The First Republic and post 1966 federalism are on the opposite sides in terms of power (Weak Centre and Strong Regions; Strong Centre and Weak States), Resource Control and Allocation. On the aspects of other auxiliary parts of federalism, the two have also been on opposite sides - Parliamentary Democracy, among others. However, there is a greater peril of failing to comply with the principles establishing the federalism more in the post 1966 than the First Republic federalism, although such are at varying degrees dependent upon circumstances and geo-political and economic settings as well as the leadership commitment.

As far as revenue generation and allocation is concerned, the First Republic Regions were more viable and accountable in generation and management of their resources than the post 1966 federalism characterized by over dependence on the Centre, slow development, incessant resource conflict and corruption. For the post 1966 units of federalism, and especially the States and Local Governments, there is little or no difference in terms of quality service delivery to the people between the resource rich States and Local Governments on one hand, and the other considered to be poor or not oil producing States.

Nigerians have the choice of the federal arrangement to make. However, what determines the success or failure largely depends on compliance with the established principles guiding the operation of the federalism in relation to constitutional provisions. At any rate, those virtues of federalism - tolerance, accommodation, compromises, and heterogeneity must be wholly embraced and upheld for Nigeria to move on as one united entity.

\section{References}

Adedeji, A. O (2017). Federal solution and Nigeria's democracy. Journal of Social Science and Public Policy. 7(1).

Adedeji, A. O., \& Ezeabasili, I. E. (2018). Restructuring and clamour for true federalism in Nigeria: A comparative analysis. Advances in Social Sciences Research Journal, 5(2), 160-168.

Ahmed, A. V., Falaye, A. J., Oloni, F. E., \& Okeke, J. (2017). Fiscal federalism and economic growth in Nigeria. Nigerian Journal of Banking, Finance and Entrepreneurship Management, 3(2). 1- 
20.

Aka, P. C. (2017). Why Nigeria needs restructuring now and how it can peacefully do it. Denv. Journal of International Law \& Policy, 46, 123.

Amusan, L., Saka, L., \& Omede, A. J. (2017). Sovereign wealth fund and fiscal federalism in Nigeria (2011-14): An assessment of contending issues. Regional \& Federal Studies, 27(4), 441-463.

Anderson, G. (ed.) (2012), Oil and gas in federal countries. Ontario: Oxford University Press.

Arowolo, D. (2011). Fiscal federalism in Nigeria: theory and dimensions. Afro Asian Journal of Social Sciences, 2(2), 1-21.

Babawale, T. (2001). The rise of ethnic militias, de-legitimisation of the state, and the threat to Nigerian federalism. West Africa Review, 3(1).

Burgess, M. (2006). Comparative federalism: Theory and practice. London: Routledge.

Charles, N. (2013). Fiscal federalism in Nigeria: Addressing issues of resource control. International Journal of Advances in Management and Economics, IJAME, 2(6).

Constitution of the Federal Republic of Nigeria, 1999. Lagos: Government Printer.

Deng, F. M., Deng, D. J. Deng, D. K., \& Jiménez, V. (2008). Identity, diversity, and constitutionalism in Africa. Washington, DC: United States Institute of Peace.

Dinneya, G. (2006). Political economy of democratisation in Nigeria. Lagos: Concept Publications

Ejobowah, B. J. (2010), Territorial pluralism: assessing the ethno-federal variant in Nigeria. Regional and Federal Studies, 20(2), 251-274.

Elaigwu, J. I. \& Akindele, R. A. (eds). (1996). Foundations of Nigerian federalism: 1960- 1995. Abuja: National Council on Inter Governmental Relations.

Elaigwu, J. I. (2017). The politics of federalism in Nigeria. London: Adonis \& Abbey Publishers.

Ewetan O.O (2012). Fiscal federalism in Nigeria: Theory and practice. International Journal of Development and Sustainability. 1(3).

Fessha, Y. T. (2017). The original sin of Ethiopian federalism. Ethnopolitics, 16(3), 232-245.

Friedman, A. B. (2018). States, Countries, and Peoples: A comparative look at bicameralism in African federal States. Fletcher F. World Affairs. 42(2), 165.

George, O., Yusuff, K. M., \& Cornelius, N. (2017). The good, the bad, and the ugly in the melting pot: The challenges of Nigerianising diversity management. Equality, Diversity and Inclusion: An International Journal, 36(3), 238-254.

Idris, N. M. (2018). Some comparisons between the Nigerian and South African fiscal regimes regarding an individual's tax residence. Obiter, 39(1), 76-84.

Levan, A. C. (2017). Reciprocal retaliation and local linkage: Federalism as an instrument of opposition organizing in Nigeria. African Affairs, 117(466), 1-20.

LeVan, A. C., \& Ukata, P. (eds.). (2018). The Oxford Handbook of Nigerian Politics. Oxford: Oxford University Press.

Lugard, F. L. S. (1906). A tropical dependency: An outline of the ancient history of Western Sudan with an account of the modern settlement of Northern Nigeria. New York: Barnes and Nobles.

Mohammed, I. S., Othman, M. F. B. and Osman, N. B. (2019). Uncovering the systematic genocide against the Hausa-Fulani and Muslims groups in Nigeria. Journal of Business and Social Review in Emerging Economies, 5 (2), 247-262. https://10.26710/jbsee.v5i2.826

Mohammed, I. S. \& Aisha, A. A. (2020). Federalism: An overview of the Nigerian perspective. Beau Bassin, Mauritius: Lambert Academic Publishing.

Mohammed, I. S. \& Aisha, A. A. (2017). Introduction to Nigeria's foreign policy and international relations. Saarbrücken, Deutschland: Lambert Academic Publishing.

Mohammed, I. S. (2018). Integrated profile of northern Nigeria. Beau Bassin, Mauritus: Lambert Academic Publishing.

Mohammed, I. S., Aisha, A. A., \& Saidu, A. (2018). Nigerian political development. Beau Bassin, Mauritius: Lambert Academic Publishing.

Last, M. (2018). From Borno to Sokoto: Meaning and Muslim identities in Northern Nigeria. In A. C. Levan \& P. Utaka (eds.). A tropical dependency: An outline of the ancient history of Western Sudan with an account of the modern settlement of Northern Nigeria (pps. 19-32). New York: 
Barnes and Nobles.

National Bureau of Statistics (NBS). (2016). Social statistics report 2016. Abuja, Nigeria: National Bureau of Statistics (NBS).

Onyishi, A. O., \& Iwundu, I. E. (2017). Fiscal federalism and local government revenue base. International Journal of Communication, 12(1), 78-103.

Othman, M. F. B., Osman, N. B. \& Mohammed, I. S., (2019). Restructuring Nigeria: the dilemma and critical issues. Journal of Business and Social Review in Emerging Economies, 5(1), 79-98. https://doi/10.26710/jbsee.v5i1.567

Salami, A. (2011), Taxation, revenue allocation and fiscal federalism in Nigeria: issues, challenges and policy options. Economic Annals, LVI (189), 27-50.

Saidu, B., Rasheed, Z. H., Zakuan, U. A. B. A. and Yussoff, K. Z. B. H. (2019). Restructuring and the dilemma of state police in Nigeria: to be or not to be? Journal of Business and Social Review in Emerging Economies. 5(1), 41-50. https://doi/10.26710/jbsee.v5i1.554

Shagari, S. (2001). Shehu Shagari: Beckoned to serve, an autobiography. Ibadan: Heinemann Educational Books.

Shehu, I. M. \& Buba, A. (2016). Basics of Nigerian citizenship and Government education. Saarbrücken, Deutschland: Lambert Academic Publishing.

Shehu, I. M., Othman, M. F. B., Osman, N., B., (2017). Ethno-religious and regional rivalry in Nigeria: An old and creeping trend. Asian Journal of Multidisciplinary Studies, 5(5), 14-23.

Suleiman, M. D., \& Maiangwa, B. (2017). Nigeria and the 'making' of combative identities. African Identities, 15(3), 260-277.

Tafawa Balewa, A. (1962). Mr. Prime Minister. Lagos: Government Printer.

THISDAY. 1998. November 17. Vol. 4, No. 1305. (pps. I-IXLIV);

Unegbu, O. C. (2003). Nigeria: bellwether of African democracy. World Policy Journal, 20(1), 41-47.

Usuanlele, U., \& Ibhawoh, B. (Eds.). (2017). Minority Rights and the National Question in Nigeria. Springer.

Verjee, A. (2017). Nigeria: a new history of a turbulent century. International Affairs, 93(5), 1278-1279.

Wheare, K.C (1963). Federal Government. London: Oxford University press. 